Human palaeontology and prehistory

\title{
Insights into the earliest agriculture of Central Portugal: Sickle implements from the Early Neolithic site of Cortiçóis (Santarém)
}

\section{Regards sur les débuts de l'agriculture dans le Centre du Portugal: des éléments de faucille du site Néolithique ancien de Cortiçóis (Santarém)}

\author{
António Faustino Carvalho ${ }^{\mathrm{a}, *}$, Juan F. Gibaja ${ }^{\mathrm{b}}$, João Luís Cardoso ${ }^{\mathrm{c}}$ \\ a Universidade do Algarve, FCHS, Campus de Gambelas, 8000-117 Faro, Portugal \\ b Consejo Superior de Investigaciones Científicas (CSIC-IMF), 08001 Barcelona, Spain \\ c Universidade Aberta and Centro de Estudos Arqueológicos do Concelho de Oeiras, 2784-501 Oeiras, Portugal
}

\section{A R T I C L E I N F O}

\section{Article history:}

Received 6 August 2012

Accepted after revision 28 September 2012

Available online 8 January 2013

Presented by Yves Coppens

\section{Keywords:}

Sickle typologies

Use-wear

Early Neolithic

Portugal
Agriculture

\section{A B S T R A C T}

Direct evidence of agriculture in Early Neolithic Portugal is almost non-existent, so there are very disparate estimates of the role played by agriculture during the period. Recent excavations at Cortiçóis, a newly discovered Early Neolithic site in central Portugal, revealed the first recognizable sickle implements and therefore relevant artefactual evidence of agricultural practices. These are typologically similar to Andalusian and Valencian sickles, reflecting a common technological tradition in southern Iberia during the period (c. $5600-4000$ cal BC). Based on this fact, we summarize all available evidence for early agriculture in central Portugal and compare it with the Andalusian and Valencian records in order to tentatively present a model to be tested locally in future research.

(C) 2012 Académie des sciences. Published by Elsevier Masson SAS. All rights reserved.

\section{R É S U M É}

\section{Mots clés :}

Typologies de faucilles

Tracéologie

Agriculture

Néolithique ancien

Portugal
Les témoins de l'agriculture durant le Néolithique ancien au Portugal sont presque inexistants, ce qui entraîne des estimations très disparates sur le rôle joué par l'agriculture au cours de cette période. Des fouilles récentes sur le site de Cortiçóis, un site du Néolithique ancien, récemment découvert dans le centre du Portugal, ont permis la mise au jour des premiers éléments de faucilles et donc d'une preuve artefactuelle pertinente sur les pratiques agricoles. Elles sont typologiquement similaires aux faucilles andalouses et valenciennes, ce qui reflète une tradition technologique commune dans le Sud de la péninsule Ibérique au cours du Néolithique ancien (c. 5600-4000 cal BC). Partant de ce fait, nous résumons toutes les données disponibles concernant le début de l'agriculture au centre du Portugal et nous les comparons avec les registres andalous et valencien, l'objectif étant de présenter un modèle provisoire, à tester localement dans de futures recherches.

(C) 2012 Académie des sciences. Publié par Elsevier Masson SAS. Tous droits réservés.

* Corresponding author.

E-mail address: afcarva@ualg.pt (A.F. Carvalho). 


\section{Introduction}

Despite earlier attempts, a definition of the Early Neolithic of Portugal was clearly established only in 1970 by Guilaine and Ferreira, who defined it according to a two-stage development-Cardial and "l'horizon des grottes à poteries incisées et imprimées" - paralleled to the typological-cultural framework available at the time for Neolithic cave sequences from the western Mediterranean. The Portuguese sites would be the westernmost manifestations of the "Cardial culture", as well as its later, Epicardial derivative. Although still accepted today in its general structure, this model was based solely on typological comparisons of pottery assemblages recovered from sites - mostly caves excavated in the 19th and early 20th centuries - with no recorded stratigraphic contexts.

Since the 1980's, the number of sites with detailed stratigraphy and contextual records has increased dramatically, namely in the Estremadura region of central Portugal, the westernmost tip of the Neolithic expansion across the Mediterranean. These sites provided the first solid pieces of evidence concerning material cultures, settlement systems, funerary practices, absolute chronologies - which currently establishes the 5400-4000 cal BC time interval for the Early Neolithic-and subsistence strategies. Evidence related to the latter is scarce, however, and in most cases indirect. Although the presence of domestic mammals has been documented since the 1990s, direct evidence of agriculture is still completely lacking. Sediments are not usually subjected to flotation and some of the sites may have been specialized for other activities where agriculture is not expected to occur (e.g., hunting camps, shepherd shelters, necropolises). Agricultural practices in the Early Neolithic of central Portugal are therefore only tentatively characterized.

The overall food-production economy has thus been subjected to disparate interpretations, and a priori theoretical assumptions clearly dominate over empirically supported arguments. Portuguese archaeologists tend to follow one of two main perspectives on the characterization of agricultural practices:

- some defend the thesis that if the Neolithic way of life emerged after a pioneer colonization process originated in the western Mediterranean basin (as would be the case in central Portugal), it must have implied the introduction of a full range of domestic species, both animals and plants, as part of the "Neolithic package". Therefore, agriculture must have been similar in the crops and practices already documented in those regions (for a recent overview see Zapata et al., 2004; Zeder, 2008); or, as Zilhão (1997) puts it, "absence of evidence" cannot be considered "evidence of absence";

- however, most archaeologists stress the current lack of field evidence and consider agriculture to be of negligible importance or "limited" to a horticultural epiphenomenon during the Early Neolithic. The process must have been based on a piecemeal adoption of domestic plants and animals by local Mesolithic communities. According to this point of view, only in later periods, with the arrival of the "secondary products revolution" (which is still thought to occur only at the beginning of the 3rd millennium BC), did agricultural practices become fully established and constituted a relevant subsistence strategy (e.g. Jorge, 2000).

In the context of a research project on the Iron Age on the Tagus left banks, field surveying led to the discovery in 2010 of an Early Neolithic site near the modern town of Almeirim - Cortiçóis (Fig. 1), which was subsequently excavated (Cardoso et al., 2012). Among other artefacts, it revealed an assemblage of flint implements which, after their use-wear analysis, were determined to be tools used in the harvesting of cereals. This particular find at Cortiçóis implies obvious relevant repercussions on the debate about the earliest agriculture in the region. Thus, the main subject of this paper is twofold:

- to present the use-wear analysis carried out on the Cortiçóis flint tools that allowed their classification as sickle implements (analytical procedures, obtained results and interpretation), comparing them to the Early Neolithic sickle typologies of the Iberian Peninsula;

- to discuss this find in the context of available evidence for agriculture in southern Iberia (crops, their evolution through time and regional variations), building a model for the presumed agricultural practices in the Early Neolithic of central Portugal to be tested in future research.

\section{Material and methods}

\subsection{The site of Cortiçóis}

Cortiçóis is located on a vast sandy fluvial terrace gently inclined towards the Tagus River, only $2 \mathrm{~km}$ east from its modern left bank (Fig. 1). Lithic and ceramic artefacts typologically datable to the Early Neolithic were scattered all over the area, but some denser concentrations - probably the remnants of different episodes of occupation - were also visible. The largest of these was found on a platform overlooking the surrounding lower sections of the terrace and was therefore selected for excavation, which took place in September 2010.

The site is currently divided into parcels for the building of residences, a limiting factor that circumscribed the excavation to an unoccupied parcel in the platform. Testing of other parcels to evaluate possible spatial variations within the site was not possible. A $64 \mathrm{~m}^{2}$ area was excavated, corresponding to an $8 \times 8 \mathrm{~m}$ square which reached an average depth of $0.90 \mathrm{~m}$. As suspected during the surface survey, the deposit was disturbed to a depth of c. $0.80 \mathrm{~m}$ below the modern surface by deep trenching for vineyard plantation, but pottery refitting exercises allowed the measurement of the distance. As illustrated by vessels 5 (composed by two potsherds) and 6 (three potsherds) from Fig. 2, fragments were scattered through contiguous units but reaching $0.30-0.45 \mathrm{~m}$ depth. The same is true for the four polished stone tools which were all found in square A2. These facts testify the predominance of vertical, rather than horizontal, displacements. This observation reduces the possibility of mixing of contiguous occupations and points to a chronologically homogeneous Neolithic 


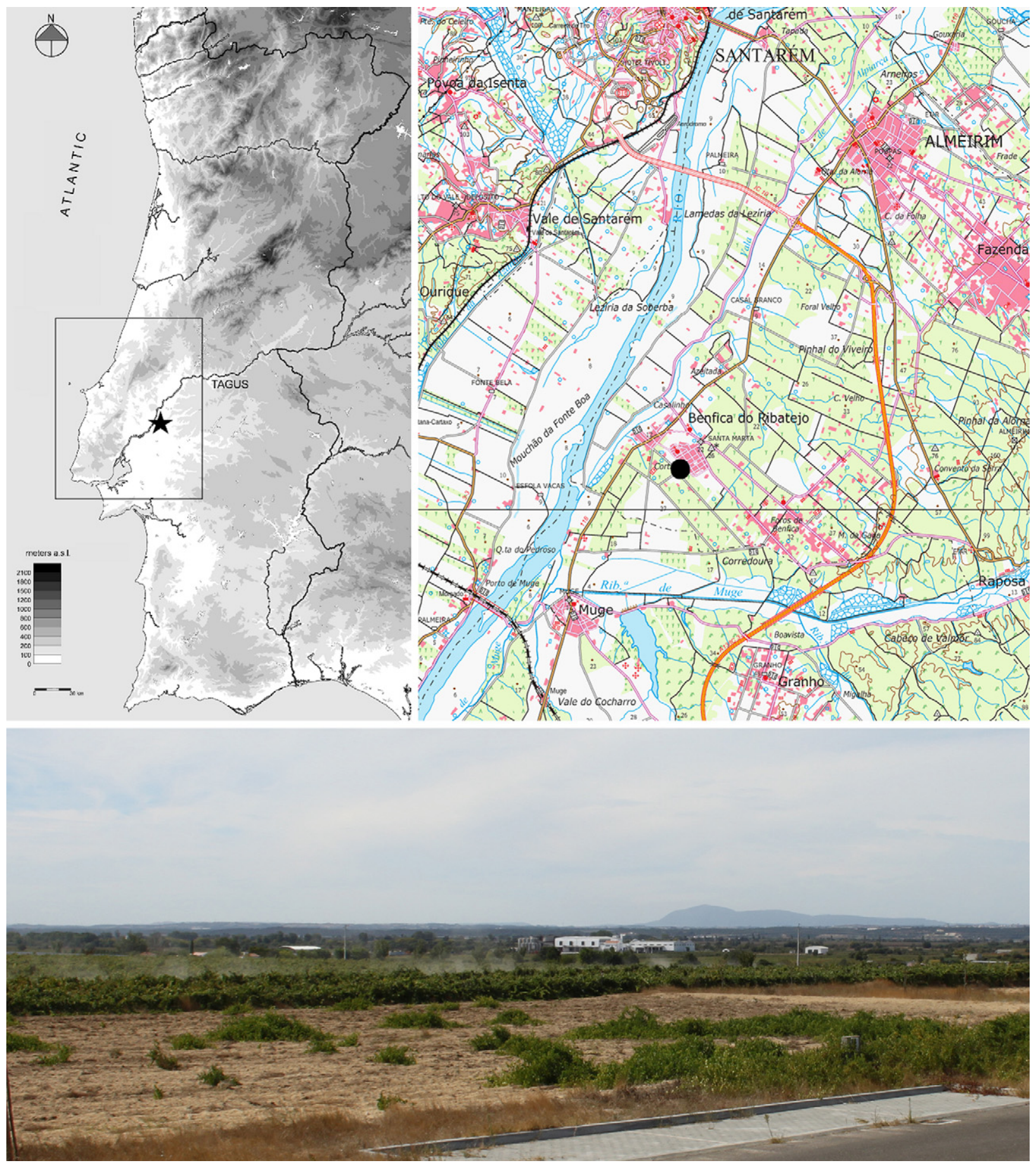

Fig. 1. Left: location of the region under study (rectangle) and the Neolithic site of Cortiçóis (star); right: site location and neighbouring area; bottom: a view of the sandy terraces and vineyards immediately ahead of the Cortiçóis platform where the excavation took place.

Fig. 1. Gauche : localisation de la région étudiée (rectangle) et du gisement néolithique de Cortiçóis (étoile); droite : localisation du gisement et de la zone environnante; en bas : vue sur les terrasses et les vignobles immédiatement en amont de la plate-forme où ont eu lieu les fouilles de Cortiçóis.

occupation in this sector of the Cortiçóis site, as also testified by its material culture.

Given the sediment acidity, Neolithic organic material was not preserved; thus radiocarbon determinations could not be used for a chronological attribution of the Neolithic occupation of the site. Chronologic and cultural attributions could only be obtained by comparisons of material culture items.

Pottery was the key dating material. Refitting allowed the reconstruction of 179 vessels, 11 (6\%) of which were 

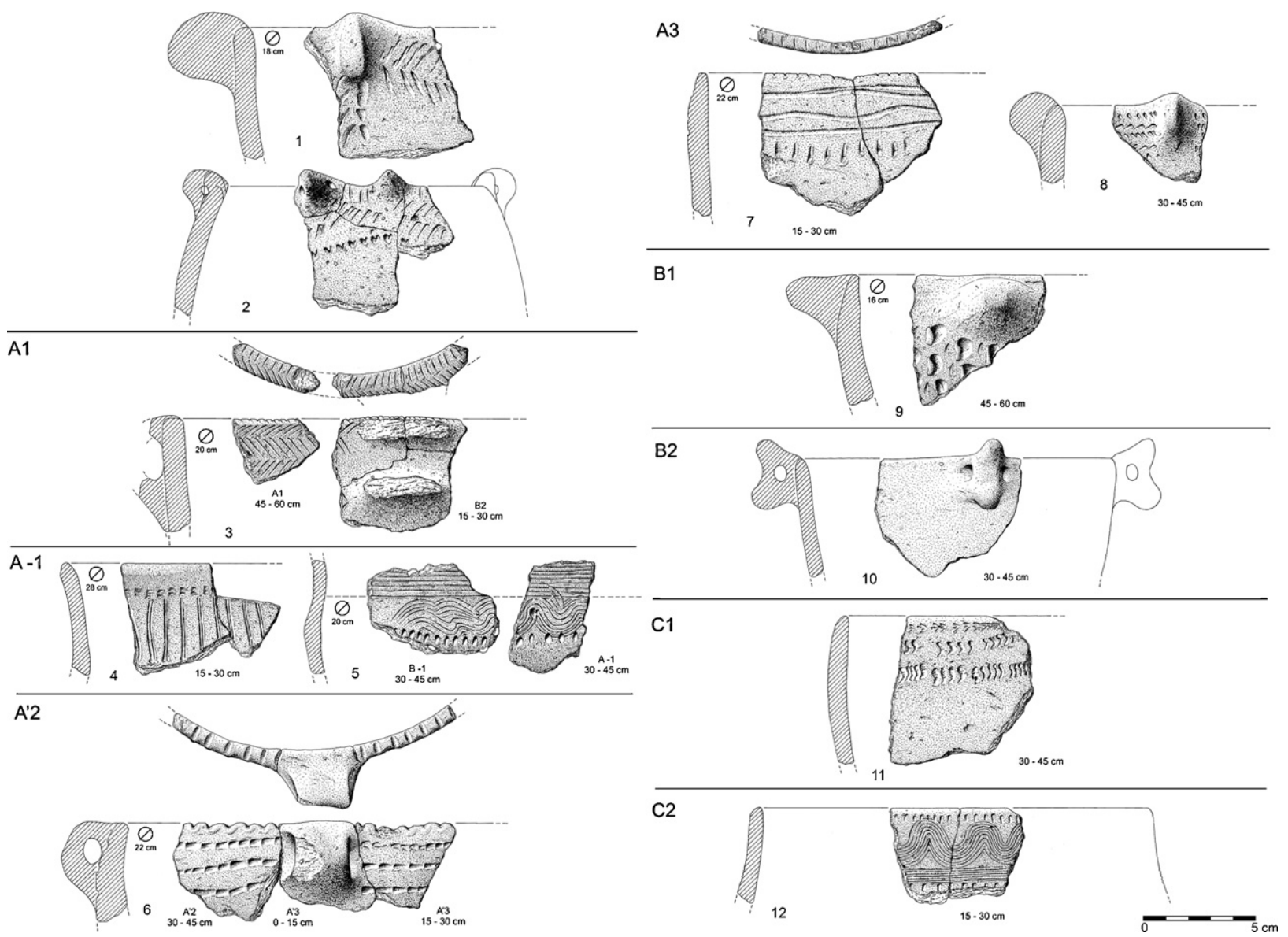

Fig. 2. Decorated pottery from Cortiçóis (drawings F. Martins).

Fig. 2. Poterie décorée de Cortiçóis (dessins F. Martins).

decorated with spine motifs obtained by sharp incision (Fig. 2: 3), wavy or straight incised lines produced by a comb (Fig. 2: 5, 12), resulting in some cases in baroquely decorated pots, and punctures, a technique that combines incision and impression. This is present under the form of boquique (Fig. 2: 6)- uninterrupted punctures forming irregular channels - and the motif known as "false acacia leaf" (Fig. 2: 1, 2, 8). Among the impressed potsherds, there is some cardial, as illustrated in Fig. 2: 11. These decorations, as well as the thick perforated handles resembling pig's heads present in some pots (Fig. 2: 10), are typical of the evolved Early Neolithic in the region. Wavy lines may specifically characterize the end of the period, probably the last quarter of the 5th millennium BC. The presence of cardial potsherds is not surprising in these later, epicardial contexts.

Polished stone tools are represented by four adzes, mainly made with locally available raw materials. The chipped stone inventory totals 1707 artefacts obtained from the knapping of flint-which amounts to $96 \%$ $(n=1630)$ of the total lithic artefacts, quartzite, quartz and rock crystal. Unlike the polished tools-, flint must have been collected in the limestone massifs of the Tagus right banks. Core typology is dominated by bipolar (direct percussion with hammer and anvil stones) and prismatic methods (18 and 9 pieces, respectively). Side-retouched flakes $(n=32)$, bladelets $(n=21)$ and notched flakes $(n=11)$ are the most common tool type (30\%, $20 \%$ and $10 \%$, respectively). Of interest is the percentage of truncated blades or bladelets $(n=5 ; 7 \%)$, some of which are oblique and with "cereal gloss" in the unretouched edge next to the truncation. Truncated blades and bladelets are in fact very scarcely represented in the evolved Early Neolithic assemblages of central Portugal, ranging from 3.5\% to $7 \%$ of the total formal tools whenever present (Carvalho, 2008). Armatures, composed mainly of segments, make up $10 \%$ $(n=11)$ of the total retouched tools, which is in perfect accordance with their normal $8-12 \%$ variation.

\subsection{Use-wear analysis of sickle implements}

Use-wear analysis of lithic artefacts was initiated by the Russian researcher S.A. Semenov in the 1930s, eventually spreading and consolidating as an autonomous line of research in the USA and Europe in the last quarter of the 20th century. Experimental frames of reference, ethnographic analogues and archaeological data, alongside the recent advances in microscopy (high resolution 
microscopes and SEM) and digital photography (high resolution photos and specific software, such as Helicon focus), allow us to approach the worked material and the kinematics involved in its transformation or processing.

During the 1980s, a broad debate took place on Near Eastern early agriculture concerning the distinction between marks on sickle implements resulting from the harvesting of wild versus domestic cereals. Explicitly, the debate's objective was to determine, through use-wear of lithic tools, when domestic cereals were first cultivated: if during the transition from the Natufian to the Pre-Pottery Neolithic or if solely during the latter period. The outcome of this debate was that, according to Unger-Hamilton (1983, 1985, 1988), domestic cereals would cause more striations on lithic implements due to previous soil ploughing, a conclusion not fully accepted by Anderson (1983, 1988, 1992) and Anderson et al. (1991).

Independently of the conclusions reached, the above example shows that sickle implements are in any circumstance crucial pieces of evidence in the study of farming communities since they can be directly connected to the harvesting of cereals and therefore provide evidence of agricultural techniques and practices. This is particularly important in archaeological sites with no carpological preservation, such as the case of Cortiçóis, where a sample of nine flint tools revealed the first well-documented Neolithic sickles in western Iberia.

The methodology employed in their analysis has been widely described before (Gassin, 1996; González and Ibáñez, 1994; Jensen, 1994; Keeley, 1980; Vaughan, 1985; etc.) and has recently undergone further recent developments (Gibaja, 2008; Ibáñez et al., 2008). A binocular lens Nikon SMZ-10A (allowing $10 \times$ to $90 \times$ magnifications) and metallographic lens Olympus BH2 (50× to $400 \times$ magnifications) were used in conjunction during the analyses. Given the absence of concretions, the lithic tools were only washed with clean water and soap, making the use of acid solutions unnecessary.

Our experiments on the harvesting of different plants (see references above), both wild (reed, fern, cane) and domestic (wheat, barley), show that undifferentiated usewear is formed if lithic implements are submitted to a short period of use (usually 30-60 min, depending on variables such as plant humidity, amount of plant silica, type of flint, etc.). At this stage, micro-polish is not well developed and the distinction between cereals and wild plants is rather difficult. However, when a higher degree of wear is reached after more intensive use of the implement, the harvesting of cereals creates a completely original series of use-wear, clearly distinguishable from the harvesting of other nonligneous plants (see also Yamada, 2000). In this case, a very extensive, bulky and homogeneous micro-polish is obtained, sometimes reaching the longitudinal nervures of the flint blade. This micro-polish is not very lustrous, but presents a very dense texture that extends to the inner parts of the implement's topography; within this micropolish numerous micro-cavities and striations (mainly if the harvesting takes place at the stalk's lower sections) of different shapes and sizes are evident, and so-called "comet-like" striations also become very common. The formation and development of use-wear in lithic artefacts are also dependent on the specific characteristics of the raw material and its resilience to human and natural factors. Thus, deciphering the successive impacts on lithic surfaces and wear marks will permit a more comprehensive analysis. van Gijn (1989: 40) synthesises this approach with the following words: "It is suggested, however, that it is possible, at least experimentally, to differentiate between polishes from cutting reeds and those from reaping domesticated cereals, in the sense that the former have a 'wet', fluid-like appearance (even in the case of a well-developed polish), while the latter have a somewhat rougher and flatter polish".

In the Cortiçóis case, the sampled tools display strong polishing, probably resulting from the post-depositional abrasive effect of the sandy sediments. This fact prevented an easy recognition of micro-polish generated by the processing of softer materials such as meat, fish or fresh skin. However, the observed micro-polish is well developed and extends along most of the tools' edges, permitting its diagnosis as marks produced during the harvesting of cereals or other non-ligneous plants. In spite of the fact that hafting may leave minor and isolated marks on flint implements (Roots, 2003), the Cortiçóis sickle flints clearly show, not only cereal micro-polish distributed along the tool's edges, but also some blank modification allowing the recognition of the way they were hafted. The hafting mode is recognizable through the micro-polish distribution along the edge of the implement. When cereal polish is well developed, such as in the case of Cortiçóis, the limit of the haft is even recognizable to the naked eye.

In sum, comparing the mentioned use-wear characteristics of the Cortiçóis flint implements with our experiments we can securely conclude these were hafted in sickles used, at least, for cereal harvesting (Fig. 3). By "at least" we mean we cannot confirm the possibility of these sickles being used solely in cereal harvesting. According to modern analogues, farmers occasionally use their metal sickles in other tasks, such as the removal of weeds from cultivated plots; the problem is the detection of such activities. In the Cortiçóis case, cereal harvesting activities were detected but those less systematic activities, although probable, did not leave noticeable use-wear on the lithic implements.

The nine flint tools from Cortiçóis recognized as sickle implements also share a few common morphological attributes: they range in size from $3.0-4.0 \mathrm{~cm}$ in length, $1.0-1.3 \mathrm{~cm}$ in width and $0.2-0.3 \mathrm{~cm}$ in thickness and were all made on blade or bladelet blanks segmented by abrupt retouch at one or both ends in order to facilitate its parallel insertion in the haft, originating formal tools classified as straight or oblique truncations. This procedure permits the easy replacement of any implement lost or broken during the harvest, or one which has lost its effectiveness. On the other hand, these relatively standardized sizes (specially widths) and retouch options are clearly related to the implement's hafting mode. Average widths also indicate these blanks were obtained from prismatic rather than from bipolar cores.

According to experiments (e.g. Anderson, 1992; Gibaja, 2003; Unger-Hamilton, 1991), the number of striations is directly related to the distance from the soil where the cereal stalk is cut: if the cut is closer to the soil the number 


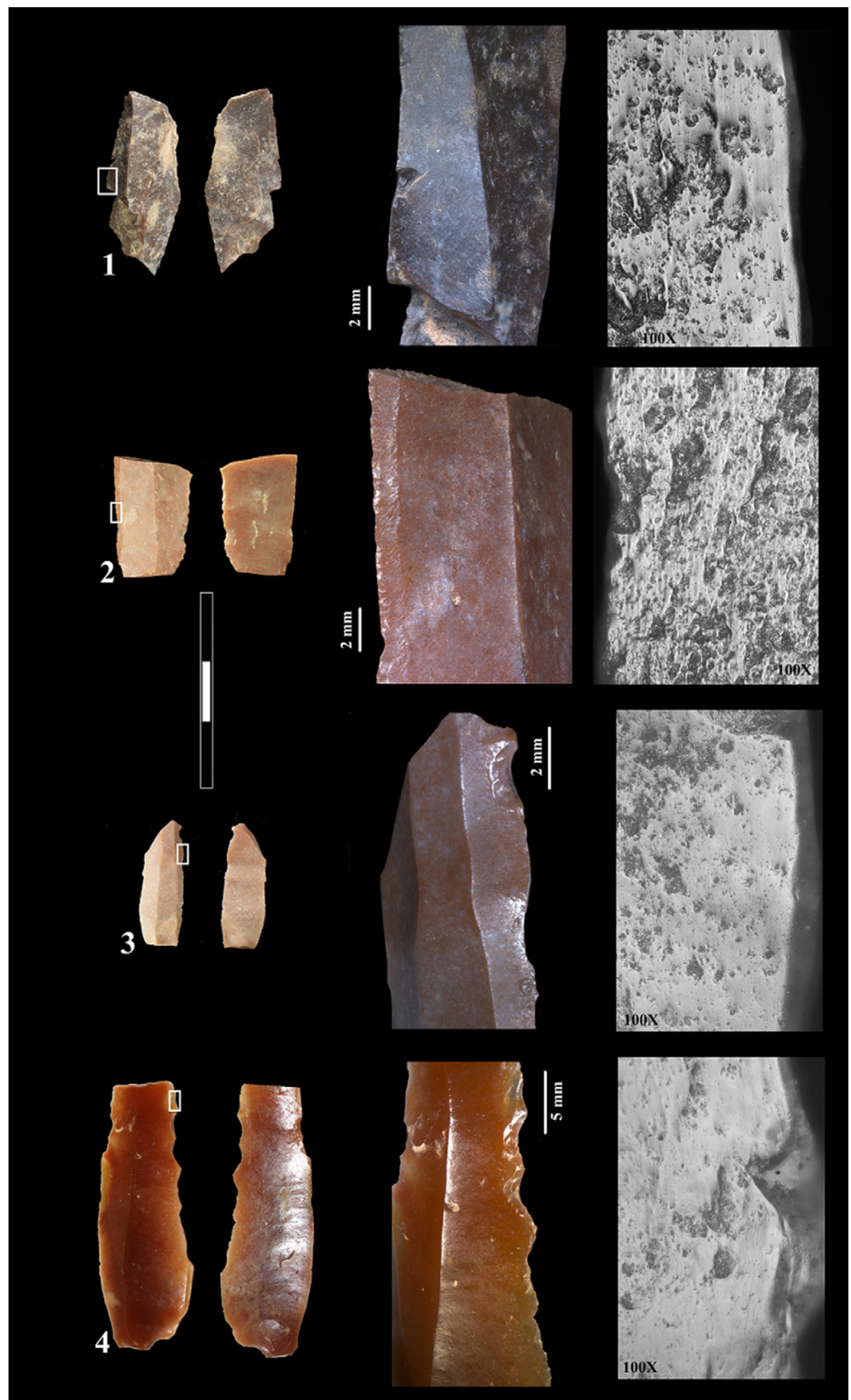

Fig. 3. Evidence of cereal polish on blades. Fig. 3. Lames avec poli de céréales. 
of striations is considerable higher due to the earth particles adhering to the lower part of stalks. Other authors have shown that the number of striations is more a factor of the degree of development of polish rather than the height of cut (Ibáñez et al., 2009). At Cortiçóis, the number of striations within the polish is very low; this means that the harvesting took place in the middle or upper sections of cereal stalks. As a consequence, part of the stalk was left in the field - probably to be used as fertilizer or fodder - while the rest was taken to the camp site to be used as construction material, clothing, fodder, etc.

\section{Discussion}

\subsection{The Cortiçóis sickles in their Iberian context}

Three small flakes and broken bladelets from the Early Neolithic site of Valada do Mato (dated to c. 4900 cal BC), in the Alentejo region of South Portugal, were the first flint tools to be tentatively classified as sickle implements in the country after their use-wear analysis. However, these artefacts were poorly preserved and their hafting technique could not be clearly recognized (see Gibaja et al., 2002: 220-221, for a detailed description). As mentioned in the previous section, the distribution of polish on the flint implements allowed us to infer the hafting technique in the case of Cortiçois. Here the polish is slightly diagonal to the tool's edge $\left(35^{\circ}-50^{\circ}\right)$ and the opposite edge was inserted in the groove of the haft with mastic. This explains the absence of polish (as illustrated in Fig. 4) and the presence of abrupt retouch. Retouch was meant to facilitate hafting, to prevent damaging the inner part of the groove with sharp edges, and to adapt the blade's morphology to the linear axis along which all the sickle implements were inserted (Fig. 5). In these retouched areas, there is occasionally some light polish with striations parallel or oblique to the backed edge. These may have been generated when inserting the flint in the groove and/or as a result of the sickle's use in harvesting (Fig. 6).

These types of implements and their hafting techniques - thus, the sickle typology-are similar to those documented at other Early Neolithic sites in the Valencia and Andalusia regions, respectively dated from the middle and last quarter of the 6th millennium BC onwards (Gibaja et al., 2010). However, different types of sickles are recorded in the northern regions of Iberia and Southeast France. Elongated flakes or large blades (3-8 cm length), with cereal polish parallel to the edge, were inserted along the haft of sickles abundantly documented in several Catalonian sites dated to the passage from the 6 th to the 5 th millennium BC (Gibaja, 2003). This same type of sickle is also known at Early Neolithic sites located in the French regions of Languedoc and Provence (Gassin, 1996). Some isolated sites from northern Iberia, dated to the end of the 6th millennium, yielded sickles composed of a single, large blade inserted diagonally $\left(60^{\circ}-75^{\circ}\right)$ to the haft (Gibaja, 2008; Terradas et al., 2010). Of these sites, the most spectacular find came from the submerged lacustrine dwelling at La Draga, where a wooden sickle was found with a blade fragment still inserted in the groove (Palomo et al., 2011).
In sum, to date, three different types of sickles are known to have been in use during the Early Neolithic in the Iberian Peninsula and the Gulf of Leon. As evidenced in Fig. 7, Cortiçóis clearly integrates central Portugal in the Valencian/Andalusian typo-technical tradition, a conclusion that raises the important question of whether these sickle types are correlate to a specific set of cultivated cereal species. If so, it may be indicative of Early Neolithic crops and agricultural practices in Portugal.

\subsection{Might crops and agricultural practices in the Early Neolithic of central Portugal be similar to the southern Iberian pattern?}

The evidence presently used to infer Early Neolithic subsistence strategies in central Portugal can be summarized as follows:

- faunal assemblages. The number of Early Neolithic sites with faunal remains is scarce, as is also the corresponding number of identifiable specimens. The available zooarchaeological evidence (Carvalho, 2008) points to two main conclusions:

1 domestic species - sheep and/or goat (Ovis aries/Capra hircus) and cattle (Bos taurus) - are present at the Earliest Neolithic sites, attributed to the 5400-5200 cal BC time period (Cardial) and throughout the 5th millennium BC,

2 these occur alongside wild species, mainly wild boar (Sus scrofa) and red deer (Cervus elaphus), testifying mixed strategies of animal exploitation. The relative proportions between domestic and wild specimens clearly need larger faunal assemblages to provide a stronger statistical analysis;

- stable isotopes from human bones. Lubell et al. (1994) produced a pioneer study in Portugal in the mid-1990s based on stable isotope analysis of human bone collagen. According to these authors, there was a major subsistence shift at the onset of the Neolithic: Mesolithic groups based their diet on marine and terrestrial foods, while the Neolithic subsistence was more dependent on terrestrial food sources (herbivore meat and plant foods), presumably reflecting the introduction of a farming economic system. More recently obtained stable isotopic analyses, although less systematic, seem to corroborate these conclusions (Carvalho, 2008, 2010);

- microfauna from Early Neolithic deposits. According to the available palaeontological record, two Murid species are unknown during the Pleistocene (Póvoas, 1991) but make their appearance during the Neolithic: the Algerian mouse (Mus spretus) and the house mouse (Mus musculus). These species are usually associated with the spread and development of the Neolithic in Europe, the first inhabiting deforested areas, the latter living in sedentary human settlements. Both species are present from the evolved Early Neolithic (5th millennium BC) onwards at the Pena d'Água Rock-shelter (Póvoas, 1998), indirectly demonstrating the existence of agricultural plots in the immediate vicinities of the site. This and other finds from later Neolithic and Chalcolithic contexts of central and southern Portugal clearly contradict the thesis of Cucchi 


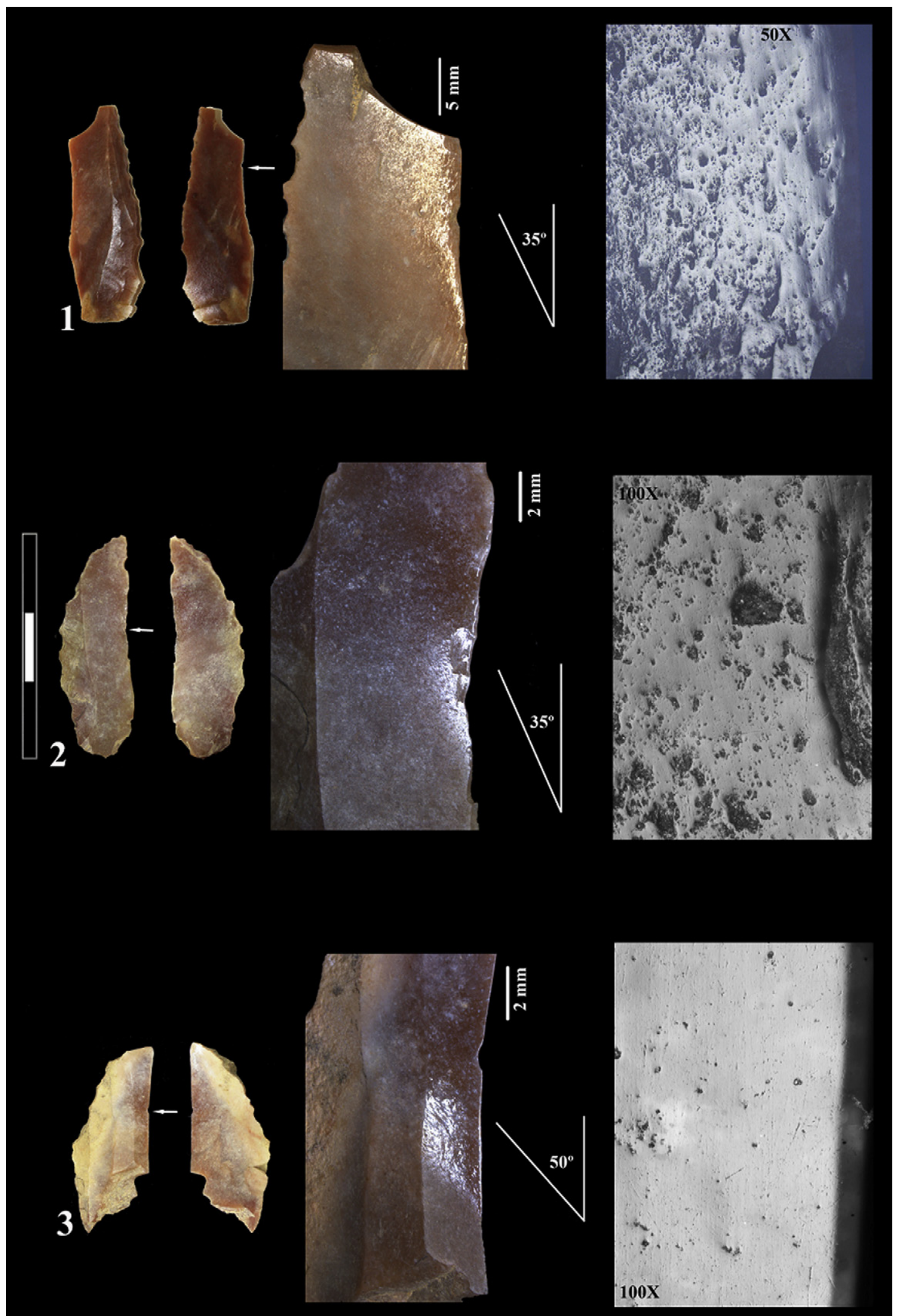

Fig. 4. Flint blade used in cereal harvesting. Macroscopic photos show diagonal distributions of polishing on the blade surface. Fig. 4. Lame de silex utilisée pour la récolte de céréales. Les photos macroscopiques montrent des distributions diagonales du poli sur la surface de la pièce. 


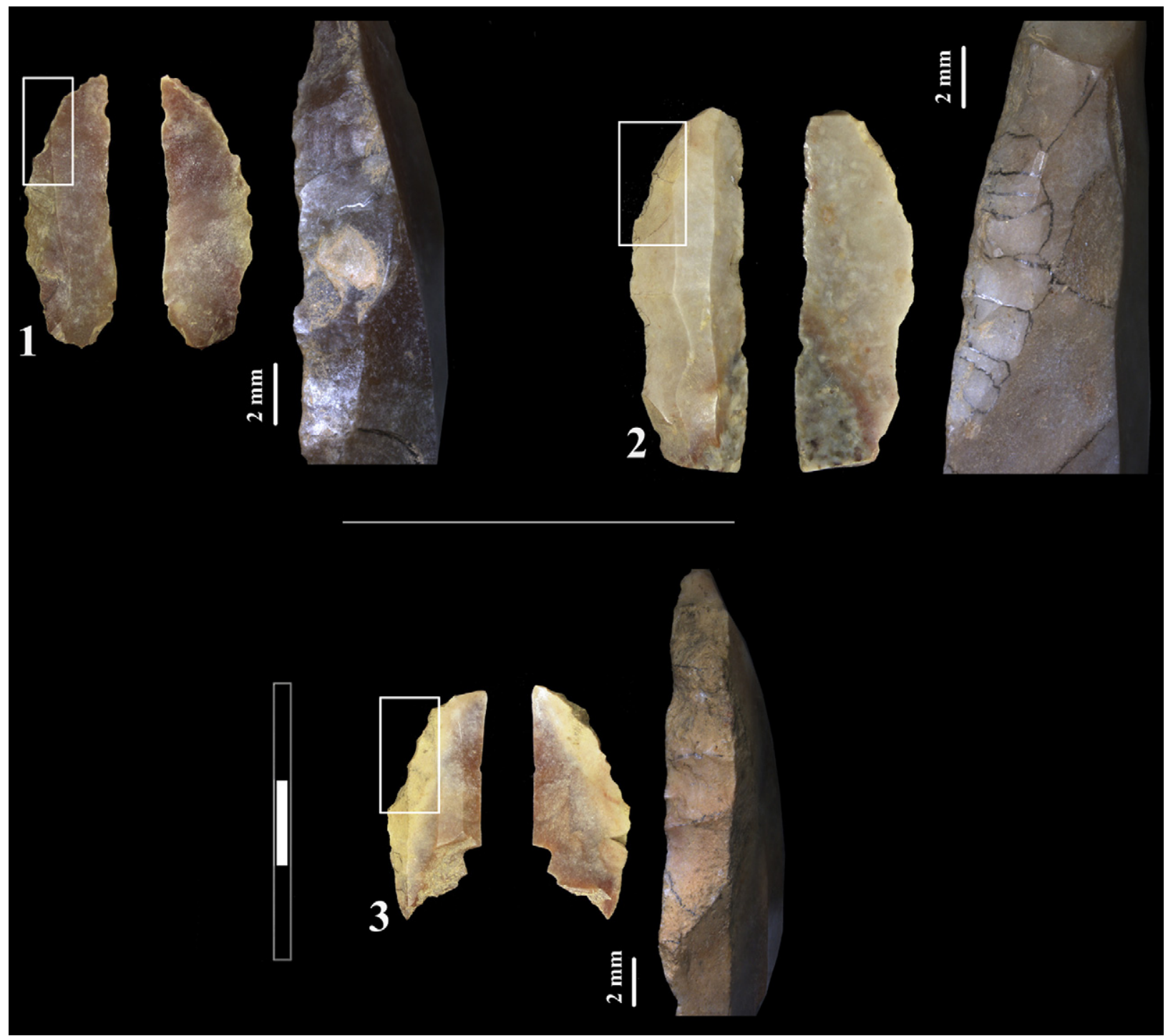

Fig. 5. Side retouch of some sickle implements made to adapt and facilitate their insertion in the handle.

Fig. 5. Retouche latérale de quelques éléments de faucille pour adapter et faciliter leur insertion dans un manche.

et al. (2005), according to which these rodents would not have colonized the western Mediterranean before the Iron Age.

Until now the earliest record of carpological evidence documenting agriculture in central Portugal is dated to the Chalcolithic (c. 3000 BC) at the famous fortified site of Vila Nova de São Pedro, where burnt remains of wheat, barley, broad bean and flax were exhumed during the 1930-1950 excavations (Paço, 1954). Palynological data, on the other hand, is restricted in the region to cores made at different locations in the Tagus Valley (Van Leeuwaarden and Janssen, 1985; Vis et al., 2008), which provides insights only in terms of local species change, not human impact.

Recently, Pérez et al. (2011) published an important synthesis of the Early Neolithic palaeobotanic evidence from several sites located in central Andalusia. According to these authors, agriculture is documented in the region from $5300 \mathrm{cal}$ BC and is represented by a diversified assemblage of crops consisting of cereals, mainly freethreshing wheats-Triticum aestivum/durum-and naked barley-Hordeum vulgare var. nudum - and pulses - broad bean (Vicia faba), pea (Pisum sativum) and lentil (Lens culinaris), along with flax (Linum usitatissimum) and poppy (Papaver somniferum), which had been cultivated at least since the end of the following millennium. When interpreting the Andalusian pattern at broader scales, the authors note the higher frequency of hulled wheats-einkorn (Triticum monococcum) and emmer (Triticum dicoccum) - in the neighbouring Valencia region (Pérez, 2005), which strongly contrasts with the Andalusian pattern despite their common sickle types. This contrast gives rise to the interpretation that "the observable panorama in these early moments of agrarian development is really 

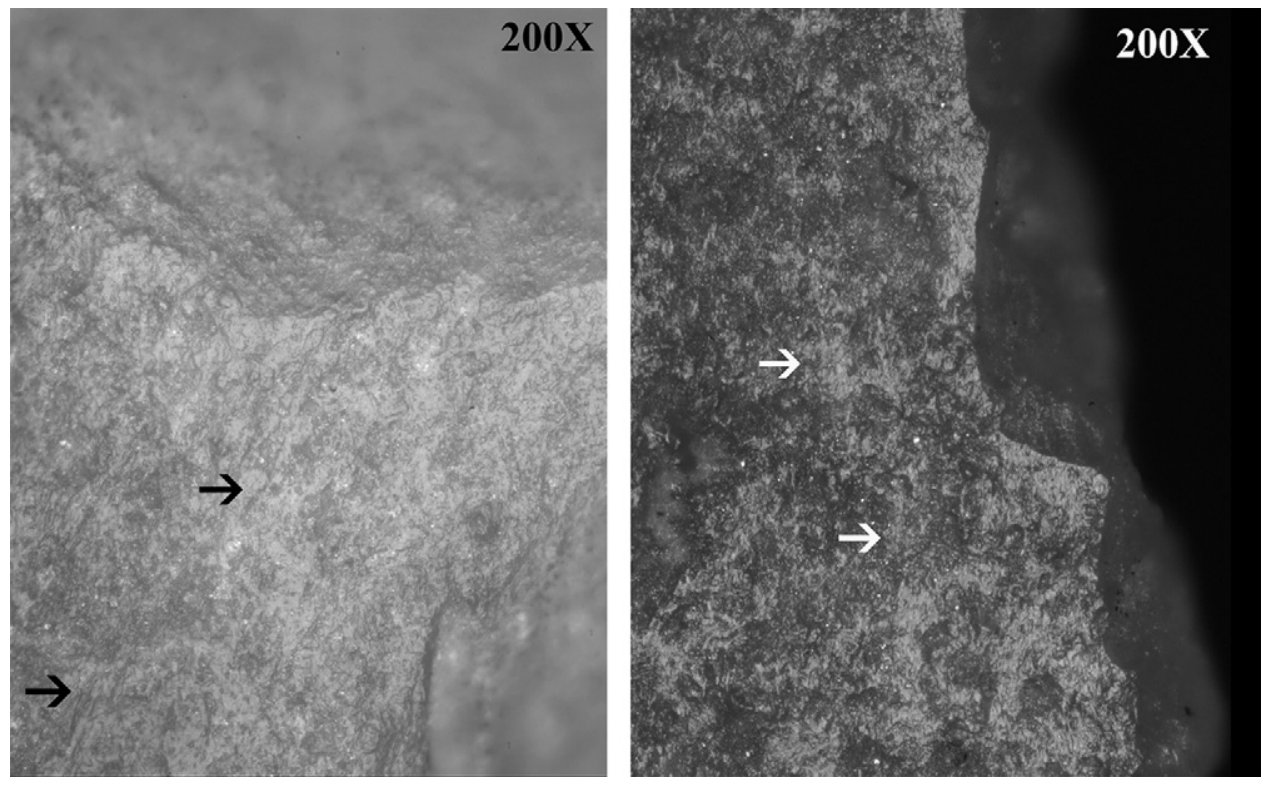

Fig. 6. Observed modifications on the inserted sides of two of the Cortiçóis sickle implements, where light polishing next to striations is visible. Fig. 6. Modifications observées sur les côtés insérés de deux des éléments de faucille de Cortiçóis, où un léger poli accompagnant des stries est visible.

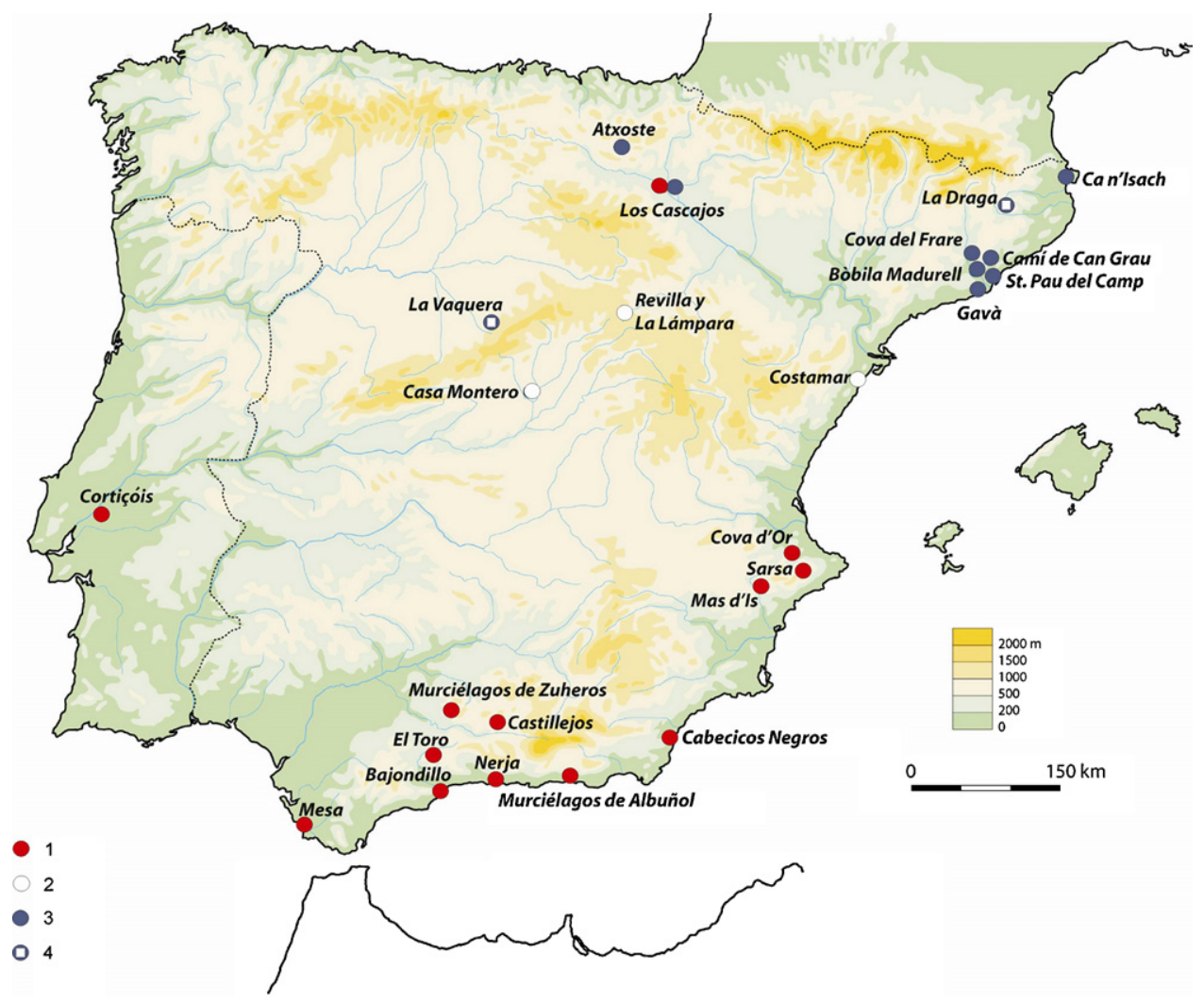

Fig. 7. Sickle types from Early Neolithic Iberia. 1: sickles with oblique implements; 2: sickles with large blade inserted diagonally; 3 : sickles with large blades parallel to the haft; 4 : sickles of types 2 and 3.

Fig. 7. Types de faucilles du Néolithique ancien de la péninsule Ibérique. 1 : faucilles avec des éléments obliques, 2 : faucilles avec une grande lame insérée en diagonale, 3 : faucilles avec de grandes lames parallèles à la poignée, 4 : faucilles de types 2 et 3 . 


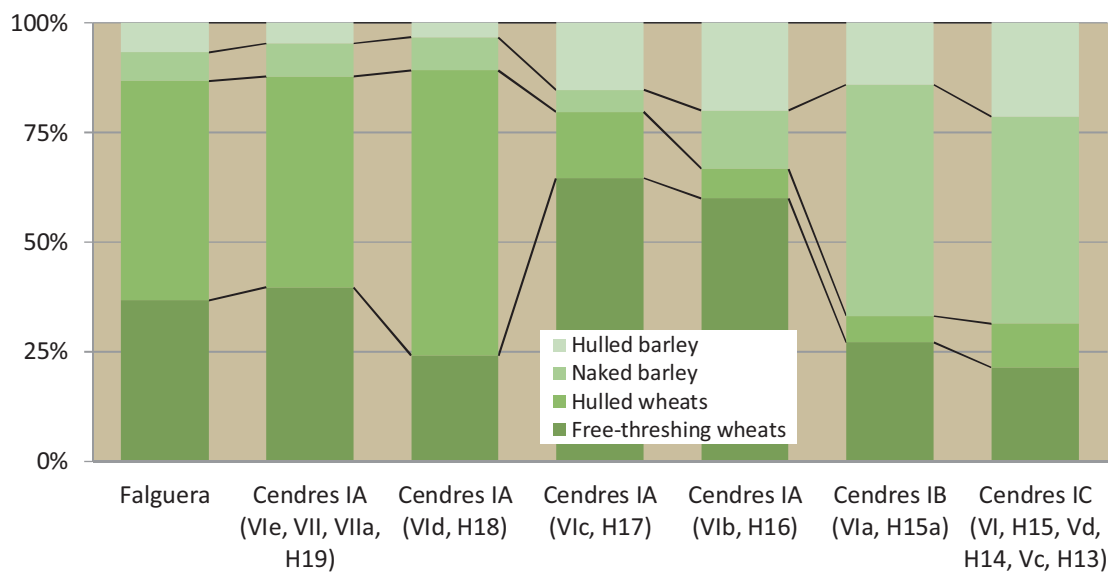

Fig. 8. Evolution of cereal assemblages in the Neolithic of Valencia: Falguera (Pérez, 2005: table 1) and Cendres (Badal, 2009: table 8.1). Approximate radiocarbon chronologies (cal BC): Falguera: c. 5500; Cendres IA: 5500-5200; Cendres IB: c. 5150; Cendres IC: c. 4800.

Fig. 8. Évolution des assemblages de céréales dans le Néolithique de Valencia : Falguera (Pérez, 2005: tableau 1) et Cendres (Badal, 2009: tableau 8.1). Chronologies approximatives au radiocarbone (cal BC): Falguera : c. 5500; Cendres IA : 5500-5200; Cendres IB : c. 5150 ; Cendres IC: c. 4800.

complex, with different situations which surely reflect the presence of diverse traditions" in Andalusia and the Valencian region, respectively (Pérez et al., 2011: 68; Spanish original).

However, an alternative interpretation is likely. The regional differences in crops may be biased by a coarsegrained picture of the chronostratigraphic sequences in Valencia. In effect, if hulled and free-threshing wheat remains from the Falguera Rock-shelter and Cendres Cave are put into a detailed sequence, a trend of increasing percentages of the latter becomes evident throughout the $5600-4000$ cal BC time span (Fig. 8), as Buxó (1997) stated. The inversion of the relation between both types takes place in the middle of "Neolithic IA" (Cardial), around $5300 \mathrm{cal}$ BC, at the same time as two other factors cooccur: 1) the start of increasing percentages of barley; and 2) the diffusion of agriculture in the Andalusian region. Andalusian crops, as described by Pérez et al. (2011), are therefore comparable with the pattern emerging in Valencian later Cardial sites, while sickle typologies remain the same throughout the period in both regions (see previous section).

According to several authors (e.g. Carvalho, 2010; Manen et al., 2007), a recomposition of the Early Neolithic technological systems may have occurred in Andalucia and central/southern Portugal, forming a cultural entity of its own within the Cardial tradition (as a result of local Mesolithic and/or African influences?). Although there is not necessarily a direct relationship between sickle typologies and crop assemblages (as the Valencian sequence clearly shows), the Cortiçóis evidence reinforces the plausibility of the above view. Taken as whole, this view allows us to hypothesise that crop assemblages may have also been the same in central and southern Portugal and Andalusia. Moreover, the discovery of broad bean, free-threshing wheats and naked barley $(4 \%, 35 \%$, and $61 \%$ of remains, respectively), dated to $4800-4600 \mathrm{cal} \mathrm{BC}$, at the Buraco da Pala Rock-shelter, in North Portugal (Sanches, 1997), also seems to point in the same direction.
If such a hypothesis is confirmed by future research, it may also allow the transposition to central and southern Portugal of the considerations presented by Buxó (1997: 171-172; Spanish original) concerning the corresponding Neolithic agricultural regimes: "The presence of pulses alongside cereals in the peninsular Neolithic allows us to suppose the existence of some sort of cultivation system. If in a tilled plot broad beans, lentils, peas, and grass peas are sown at the same time as cereals, it is perfectly plausible that the latter products do not have the same status as cereals and that their cultivation is more similar to a form of horticulture. If in another plot pulses are cultivated alternating with cereals, the same characteristics of the previous system occur [in the palaeobotanic record]. We thus admit both systems have their own logic and dynamics, but are not mutually exclusive, and could therefore coexist until a stabilization of cultivated areas takes place". The latter system, implying cereal-pulse rotation (rather than cereal-fallow rotation) and consequently a permanent rather than shifting agriculture, is now currently accepted by some authors as the most likely in the European Neolithic (Bogaard, 2005; Isaakidou, 2011).

However, the above conclusion is not in good accord with the settlement pattern apparently emerging from field surveys and excavations in central Portugal where, with very few possible exceptions, the vast majority of the sites were temporary. Indeed, large and permanent settlements like those known in other Iberian regions are still to be found, although the possibility exists that these sites may be buried in alluvial deposits along the banks of the Tagus tributaries, requiring specific survey and testing strategies and techniques in order to identify and record them (Carvalho, 2008).

\section{Conclusions}

In this paper we describe sickle implements recovered at the Early Neolithic site of Cortiçóis, which were analysed through use-wear and integrated in the Iberian context 
(Fig. 7). As a result, parallels were established with Early Neolithic Andalusian and Valencian sites. This allowed us to logically integrate the Portuguese territory - in particular, central Portugal - in the broader context of Neolithic farming in southern Iberia, not only in terms of sickle types, but also tentatively in terms of associated crop assemblages and agricultural practices and regimes. However, domestic plants are not yet documented in the archaeological and palaeobotanic records of the Early Neolithic and we therefore shoulder the burden of generating empirical expectations to be tested by future research.

It is our opinion that further research is needed mainly in three domains. First, the geoarchaeological study of selected river valleys in order to evaluate settlement models and to recover plant remains from permanent sites, if existent. Second, use-wear analysis of flint tools to test the results of the Cortiçóis analysis. Third and most importantly, the systematic flotation of sediments - which is far from being a common procedure in Early Neolithic research in Portugal - to recover both direct and indirect (such as microfauna) evidence of agriculture.

\section{Acknowledgments}

Archaeological excavations at Cortiçóis took place in the framework of the research on "The last huntergatherers and the first farming communities in the South of the Iberian Peninsula and North of Morocco", a project directed by A.F.C. and J.F.G., funded by the Portuguese Foundation for Science and Technology in 2008-2010 (PTDC/HAH/64548/2006). Use-wear analysis of sickle implements was carried out in the context of the project "Origins and spread of agriculture in the South-Western Mediterranean region" directed by Leonor Peña-Chocarro in 2008-2013 (ERC-2008-AdG/230561).

The authors wish to thank two anonymous reviewers for their useful comments and suggestions that helped to improve this article.

\section{References}

Anderson, P.C., 1983. A consideration of the uses of certain backed and "lustred" stone tools from Late Mesolithic and Natufian levels of Abu Hureyra and Mureybet (Syria). Travaux de la Maison de l'Orient 5, 77-106.

Anderson, P.C., 1988. Using prehistoric stone tools to harvest cultivated wild cereals: Preliminary observations of traces and impact. In: Beyries, B. (Ed.), Industries lithiques. Tracéologie et technologie. Archaeopress, Oxford (BAR International Series, 411), pp. 175-195.

Anderson, P.C., 1992. Experimental cultivation, harvest and threshing of wild cereals and their relevance for interpreting the use of Epipaleolithic and Neolithic artefacts. In: Anderson, P.C. (Ed.), Préhistoire de l'Agriculture: nouvelles approches expérimentales et ethnographiques. CNRS, Paris, pp. 179-210.

Anderson, P.C., Deraprahamian, G., Willcox, G., 1991. Les premières cultures de céréales sauvages et domestiques primitives au ProcheOrient néolithique: résultats préliminaires d'expériences à Jalès (Ardèche). Cahiers de l'Euphrates 56, 191-232.

Badal, E., 2009. ¿Cambios ambientales y/o impacto agrícola? In: Bernabeu, J., Molina, L. (Eds.), La Cova de les cendres (Moraira-Teulada, Alicante). MARQ, Alicante, pp. 135-140.

Bogaard, A., 2005. "Garden agriculture" and the nature of early farming in Europe and the Near East. World Archaeol. 37, 177-196.

Buxó, R., 1997. Arqueología de las plantas. Crítica, Barcelona.

Cardoso, J.L., Pimenta, J.; Mendes, H., 2012. Primeira notícia sobre a estação do Neolítico antigo de Cortiçóis (Benfica do Ribatejo, Almeirim).
Al-Madan 17, 177-180 [available at http://www.almadan.publ.pt/ AdendaElectronica.htm].

Carvalho, A.F., 2008. A neolitização do Portugal meridional. Os exemplos do Maciço Calcário Estremenho e do Algarve ocidental. Universidade do Algarve, Faro [available at http://ualg.academia.edu/ AntonioFaustinoCarvalho].

Carvalho, A.F., 2010. Le passage vers l'Atlantique. Le processus de néolithisation en Algarve (Sud du Portugal). Anthropologie 114, 141-178.

Cucchi, T., Vigne, J.D., Auffray, J.C., 2005. First occurrence of the house mouse (Mus musculus domesticus Schwarz \& Schwarz, 1943) in the western Mediterranean: a zooarchaeological revision of subfossil occurrences. Biol. J. Linnean Soc. 84, 429-445.

Gassin, B., 1996. Évolution socioéconomique dans le Chasséen de la grotte de l'Église supérieure (Var): apport de l'analyse fonctionnelle des industries lithiques. CNRS, Paris.

Gibaja, J.F., 2003. Comunidades Neolíticas del Noreste de la Península Ibérica. Una aproximación socio-económica a partir del estudio de la función de los útiles líticos. Oxford (BAR International Series, 1140).

Gibaja, J.F., 2008. La función del utillaje lítico documentado en los yacimientos neolíticos de Revilla del Campo y La Lámpara (Ambrona, Soria). In: Rojo, M., Kunst, M., Garrido, R., García, Í., Morán, G. (Eds.), Paisaje de la memoria: asentamientos del Neolítico antiguo en el Valle de Ambrona (Soria, España). Universidad de Valladolid, Valladolid, pp. 451-493.

Gibaja, J.F., Carvalho, A.F., Diniz, M., 2002. Traceologia de peças líticas do Neolítico antigo do Centro e Sul de Portugal: primeiro ensaio. In: Clemente, I., Risch, R., Gibaja, J.F. (Eds.), Análisis funcional. Su aplicación al estudio de las sociedades prehistóricas. Oxford (BAR International Series, 1073), pp. 215-226.

Gibaja, J.F., Ibáñez, J.J., Rodríguez, A., González, J.E., Clemente, I., García, V., Perales, U., 2010. Estado de la cuestión sobre los estudios traceológicos realizados en contextos mesolíticos y neolíticos del sur peninsular y noroeste de África. In: Gibaja, J.F., Carvalho, A.F. (Eds.), The last huntergatherers and the first farming communities in the South of the Iberian peninsula and North of Morocco. Universidade do Algarve, Faro, pp. 181-189.

González, J.E., Ibáñez, J.J., 1994. Metodología de análisis funcional de instrumentos tallados en sílex. Universidad de Deusto, Bilbao.

Guilaine, J., Ferreira, O.V., 1970. Le Néolithique ancien au Portugal. Bull. Soc. Prehistorique Fr. 67, 304-322.

Ibáñez, J.J., Clemente, I., Gassin, B., Gibaja, J.F., González, J.E., Márquez, B., Philibert, S., Rodríguez, A., 2008. Harvesting technology during the Neolithic in South-West Europe. In: Long, L., Skakun, N. (Eds.), "Prehistoric technology", 40 years later: functional studies and the Russian legacy. Archaeopress, Oxford (BAR International Series), pp. 183-196.

Ibáñez, J.J., González, J.E., Rodríguez, A., 2009. Analyse fonctionnelle de l'outillage lithique de Mureybet. In: Ibáñez, J.J.(Ed.), Le site néolithique de Tell Mureybet. Hommage à Jacques Cauvin. Oxford (BAR International Series, 1843), pp. 363-405.

Isaakidou, V., 2011. Farming regimes in Neolithic Europe: gardening with cows and other models. In: Hadjikoumis, A., Robinson, E., Viner, S. (Eds.), Dynamics of neolithisation in Europe. Studies in honour of Andrew Sherratt. Oxbow, Oxford, pp. 90-112.

Jensen, H.J., 1994. Flint tools and plant working. Hidden traces of stone age technology. Aarhus University Press, Aarhus.

Jorge, S.O., 2000. Domesticating the land: the first agricultural communities in Portugal. J. Iberian Archaeol. 2, 43-98.

Keeley, L.H., 1980. Experimental determination of stone tool uses: a microwear analysis. University of Chicago Press, Chicago.

Lubell, D., Jackes, M., Schwarcz, H., Knyf, M., Meiklejohn, C., 1994. The Mesolithic-Neolithic transition in Portugal: isotopic and dental evidence of diet. J. Archaeol. Sci. 21, 201-216.

Manen, C., Marchand, G., Carvalho, A.F., 2007. Le Néolithique ancien en Péninsule Ibérique : vers une nouvelle évaluation du mirage africain? In: Evin, J. (Ed.), XXVI ${ }^{\mathrm{e}}$ Congrès Préhistorique de France. Congrès du Centenaire: un siècle de construction du discours scientifique en Préhistoire, 3. SPF, Paris, pp. 133-151.

Paço, A., 1954. Sementes pré-históricas do castro de Vila Nova de S. Pedro. Academia Portuguesa de História, Lisbon.

Palomo, A., Gibaja, J.F., Piqué, R., Bosch, A., Chinchilla, J., Tarrús, J., 2011. Harvesting cereals and other plants in Neolithic Iberia: the assemblage from the lake settlement at La Draga. Antiquity 85, 759-771.

Pérez, G., 2005. Nuevos datos paleocarpológicos en niveles neolíticos del País Valenciano. 3rd Congreso del Neolítico en la Península Ibérica. Universidad de Cantábria, Santander, pp. 73-82.

Pérez, G., Peña-Chocarro, L., Morales, J., 2011. Agricultura neolítica en Andalucía: semillas y frutos. Menga. Revista de Prehistoria de Andalucía 2, 59-71. 
Póvoas, L., 1991. Faunes de rongeurs actuelles et du Pléistocène supérieur au Portugal; les évidences des sites de Avecasta et Caldeirão. Memórias e Notícias do MLMGUC 112, 275-283.

Póvoas, L., 1998. Faunas de micromamíferos do Abrigo da Pena d'Água (Torres Novas) e seu significado paleoecológico: considerações preliminares. Revista Portuguesa de Arqueologia 1, 81-84.

Roots, V., 2003. Towards an understanding of hafting: the macro- and microscopic evidence. Antiquity 77, 805-815.

Sanches, M.J., 1997. O Abrigo do Buraco da Pala (Mirandela) no contexto da Pré-História recente de Trás-os-Montes e Alto Douro. SPAE, Porto.

Terradas, X., Clemente, I., Gibaja, J.F., 2010. Mining tools and lithic production in a mining production context or how can the expected become unexpected. In: Capote, M., Consuegra, S., Díaz-del-Río, P., Terradas, X. (Eds.), Proceedings of the 2nd international conference of the UISPP. Oxford (BAR International Series), pp. 243-252.

Unger-Hamilton, R., 1983. An investigation into the variables affecting the development and the appearance of plant polish on flint blades. Travaux de la Maison de l'Orient 5, 243-250.

Unger-Hamilton, R., 1985. Microscopic striations on flint sickle-blades as an indication of plant cultivation: preliminary results. World Archaeol. $17,121-126$.

Unger-Hamilton, R., 1988. Method in microwear analysis. Prehistoric sickles and other stone tools from Arjoune, Syria. Oxford (BAR International Series).

Unger-Hamilton, R., 1991. Natufian plant husbandry in the southern Levant and comparison with that of the Neolithic periods: the lithic perspective. In: Bar-Yosef, O., Valla, F.R. (Eds.), The Natufian culture in the Levant. Michigan, pp. 483-520.

Van Gijn, A., 1989. The wear and tear of flint. Principles of functional analysis applied to Dutch Neolithic assemblages. Analecta Praehistorica Leidensia, Leiden.

Van Leeuwaarden, W., Janssen, C.R., 1985. A preliminary palynological study of peat deposits near an oppidum in the lower Tagus valley, Portugal. I Reunião do Quaternário Ibérico. GTPEQ/AEEC, Lisbon, pp. 225-236.

Vaughan, P., 1985. Use-wear analysis of flaked stone tools. Tucson.

Vis, G.J., Kasse, C., Vandenberghe, J., 2008. Late Pleistocene and Holocene palaeogeography of the lower Tagus Valley (Portugal): effects of relative sea level, valley morphology and sediment supply. Quaternary Sci. Rev. 27, 1682-1709.

Yamada, S., 2000. Development of the Neolithic: Lithic use-wear analysis of major tool types in the southern Levant. Harvard University, Harvard.

Zapata, L., Peña-Chocarro, L., Pérez, G., Stika, H.P., 2004. Early Neolithic agriculture in the Iberian Peninsula. J. World Prehistory 18, 283-325.

Zeder, M.A., 2008. Domestication and early agriculture in the Mediterranean basin: origins, diffusion, and impact. Proc. Natl. Acad. Sci. 105, 11597-11604.

Zilhão, J., 1997. Maritime pioneer colonisation in the Early Neolithic of the West Mediterranean. Testing the model against the evidence. Documenta Praehistorica 24, 1942. 